MATEC Web of Conferences 6, 01002 (2013)

DOI: $10.1051 /$ matecconf/20130601002

(C) Owned by the authors, published by EDP Sciences, 2013

\title{
An experimental investigation into the influence of specimen size, in-situ pore pressures and temperatures on the spalling of difference size concrete panels when exposed to a hydrocarbon fire
}

\author{
M. Guerrieri and S. Fragomeni
}

Victoria University, Melbourne, Australia

\begin{abstract}
Small and large scale reinforced concrete panels/walls were tested under hydrocarbon fire conditions to investigate concrete spalling. Results indicated that spalling is caused by the combination of thermal stresses and pore water pressure build-up. The degree and magnitude of spalling is governed by a number of inter-dependent factors including panel size, thickness and compressive strengths, all of which are investigated in this research. High strength concrete panels of increased surface area and thickness had higher degrees of concrete spalling.
\end{abstract}

\section{INTRODUCTION}

Fire costs the Australian economy approximately \$12 billion/year [1], yet the current fire building design practice standards and guidelines are not comprehensive, and provide only simplified tables derived from basic element testing. Concrete made with ordinary Portland Cement (OPC) is generally considered to have good fire resistance properties, especially compared to other structural materials such as steel and timber. However, concrete is susceptible to a less known phenomenon termed spalling in fire. Spalling of concrete in fire is the dislodgement of small pieces of concrete up to $50 \mathrm{~mm}$ (popping out) from the surface of the concrete, often explosive in nature. If the degree of spalling is significant, the load bearing capacity of the concrete member can be reduced due to: (1) reduction in its cross-sectional size, and (2) rapid increase in temperatures of the reinforcement.

The problem of concrete spalling has received attention since the 1960s [2]. Hydrocarbon fires started by hydrocarbon fuel (fuel tanker) accidents have caused spalling in three major European tunnels: Channel Tunnel in 1996, Mount Blanc Tunnel in 1999, and the St. Gotthard Tunnel in 2002 [3]. Since then, a number of studies have been conducted on the performance of concrete elements in fire, particular in relation to spalling. Often, explosive spalling has occurred to only a few specimens from a larger group of specimens that were subjected to identical testing conditions [4-6].

\section{EXPERIMENTAL INVESTIGATION}

The experimental investigation was conducted at the Centre for Environmental Safety and Risk Engineering (CESARE) at Victoria University, Melbourne, Australia.

This is an Open Access article distributed under the terms of the Creative Commons Attribution License 2.0, which permits unrestricted use, distribution, and reproduction in any medium, provided the original work is properly cited. 
MATEC Web of Conferences

Table 1. Specimen information.

\begin{tabular}{|l|c|c|c|c|c|c|}
\hline Test \# & $\begin{array}{c}\text { Specimen } \\
\text { Number }\end{array}$ & $\begin{array}{c}\text { Specimen } \\
\text { ID }\end{array}$ & $\begin{array}{c}\text { Length } \\
(\mathbf{m m})\end{array}$ & $\begin{array}{c}\text { Height } \\
(\mathbf{m m})\end{array}$ & $\begin{array}{c}\text { Thickness } \\
(\mathbf{m m})\end{array}$ & $\begin{array}{c}\text { fc } \\
(\mathbf{M P a})\end{array}$ \\
\hline 2-c & 1 & S50-25 & 300 & 300 & 50 & 25 \\
\hline 2-c & 2 & S100-25 & 300 & 300 & 100 & 25 \\
\hline 2-c & 3 & S200-25 & 300 & 300 & 200 & 25 \\
\hline 2-c & 4 & S50-80 & 300 & 300 & 50 & 80 \\
\hline 2-d* & 5 & S100-80 & 300 & 300 & 100 & 80 \\
\hline 2-d* & 6 & S200-80 & 300 & 300 & 200 & 80 \\
\hline $1-\mathrm{a}$ & 7 & L50-25 & 1100 & 1100 & 50 & 25 \\
\hline $1-b$ & 8 & L100-25 & 1100 & 1100 & 100 & 25 \\
\hline $1-c$ & 9 & L200-25 & 1100 & 1100 & 200 & 25 \\
\hline $1-d$ & 10 & L50-80 & 1100 & 1100 & 50 & 80 \\
\hline $2-\mathrm{a}$ & 11 & L100-80 & 1100 & 1100 & 100 & 80 \\
\hline $2-b$ & 12 & L200-80 & 1100 & 1100 & 200 & 80 \\
\hline 3 & 13 & W200-25 & 3360 & 3380 & 200 & 25 \\
\hline 4 & 14 & W200-80 & 3360 & 3380 & 200 & 80 \\
\hline
\end{tabular}

\subsection{Test Specimens and material properties}

Three specimen sizes $[(300 \times 300 \mathrm{~mm}),(1100 \times 1100 \mathrm{~mm})$ and $(3360 \times 3380 \mathrm{~mm})]$ of three different thicknesses $(50,100,200 \mathrm{~mm})$ were investigated. Only $200 \mathrm{~mm}$ thick specimens were investigated for the $(3360 \times 3380 \mathrm{~mm})$ panels. In addition, two compressive strengths were investigated, 25 and $80 \mathrm{MPa}$ respectively. Therefore, a total of 14 specimens were investigated which comprised of Portland cement concrete. All specimens' were reinforced with standard ribbed-wire mesh $(100 \times 100 \mathrm{~mm}$ spacing's and $6 \mathrm{~mm}$ diameter). All specimens had one layer of reinforcement placed at approximately the mid-depth of the thickness. The panels were tested in a vertical configuration under self weight only.

Table 1 represents the test specimens which have been identified by their geometric size, compressive strength and thickness which are the three parameters being investigated. For example, a specimen denoted S50-25 is identified as a small scale panel $(300 \times 300 \mathrm{~mm}), 50 \mathrm{~mm}$ thick with a 28 day compressive strength of $25 \mathrm{MPa}$. Specimens denoted with L represent the $(1100 \times 1100 \mathrm{~mm})$ specimens and specimens denoted by $\mathrm{W}$ represent the $(3360 \times 3380 \mathrm{~mm})$ specimens.

\subsection{Test furnace fire exposure and specimen setup}

The fire testing was conducted in a $3.2 \times 3.4 \times 3.4 \mathrm{~m}$ furnace chamber which has its interior lined by insulation materials that efficiently transfer heat to the specimen. The furnace can be programmed to follow both the standard and hydrocarbon time temperature curves outlined in ASTM E119 (2007) [7] which allows the furnace to reach $1100{ }^{\circ} \mathrm{C}$ within 5 minutes and works continuously for a period of 5 hours. The furnace is equipped with 6 internal type $\mathrm{k}$ thermocouples (LB, LM etc) which are position according to AS1530.4 (1197) [8] in order to program the hydrocarbon fire time temperature curve in accordance with ASTM E119 (2007) [7] and to ensure temperature equilibrium occurred around all the panels during the fire testing. Figure 1 (top) illustrates various fire curves specified by international standards in addition to the furnace thermocouple temperature recordings (bottom). As can be seen, the furnace follows the hydrocarbon fire curve within the order of approximately $2 \%$.

A special steel test rig as shown was custom built in order to house the testing of the 4 large panels $(1100 \times 1100 \mathrm{~mm})$ simultaneously in a vertical position. This was done in order to satisfy the orientation 
IWCS 2013

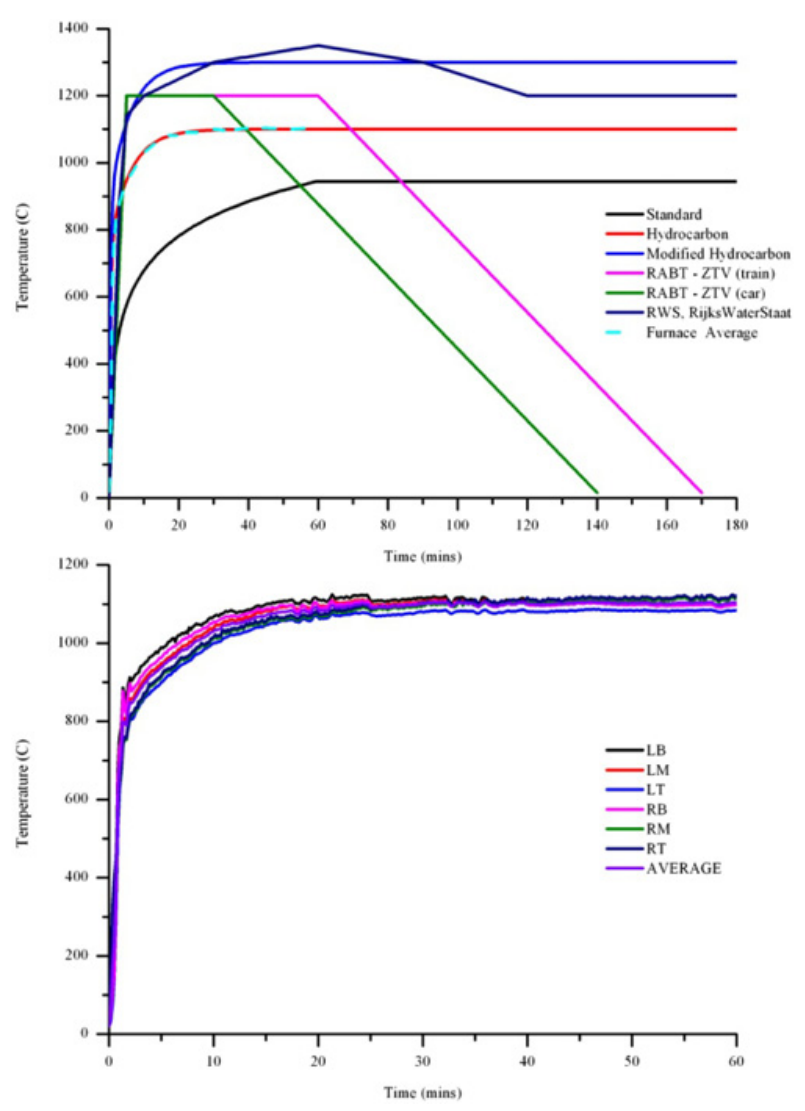

Figure 1. Fire curves (top) and gas firing hydrocarbon furnace (bottom).

of the furnace and to closely match the existence of vertical elements (such as walls). The housing rigs used were stiff enough and well insulated to support both the structural and fire loading. The steel test rig had 4 identically spaced out $(1100 \times 1100 \times 200 \mathrm{~mm}$ openings that allowed the large panels to be supported vertically against a $50 \mathrm{~mm}$ wide $\times 6 \mathrm{~mm}$ thick base plate which was welded around the entire perimeter of each opening. Therefore, the fire exposure on these large panels was $1000 \times 1000$. Due to the fact that there were 6 small and 6 large panels, in addition two 2 wall specimens $(3360 \times 3380)$, 4 fire tests were conducted as shown in Table 1. Test 1 tested 4 large panels whist Test 2 tested the remaining 2 large panels and all 6 of the small panels. 2 steel inserts measuring $1100 \times 1100 \times 200 \mathrm{~mm}$ were used in Test 2 which themselves had 4 smaller inserts of measurements $300 \times 300 \times 200 \mathrm{~mm}$ to accommodate the smaller specimens. Likewise to the large specimens, the small panels were supported vertically against a $15 \mathrm{~mm}$ wide $\times 6 \mathrm{~mm}$ thick base plate which was welded around the entire perimeter of each opening. Therefore, the fire exposure on these small panels was $270 \times 270 \mathrm{~mm}$. 2 concrete blanks $300 \times 300 \times 200 \mathrm{~mm}$ that had no significance to the experimental program were used to seal off the 2 remaining openings. Test 3 and test 4 subsequently tested the $3360 \times 3380 \mathrm{~mm}$ wall panels. For this test, the surface area that was exposed to the fire was approximately $3160 \times 3180 \mathrm{~mm}$.

During the tests, the panels were not subjected to any vertical or horizontal loading and were intended to replicate simply supported conditions. The panels were locked in under no applied stress with side brackets to prevent them from falling outwards. 


\section{MATEC Web of Conferences}

\subsection{Insitu thermocouple and pore pressure instrumentation}

To measure in-situ temperature profiles the specimens were instrumented with Type $\mathrm{K}$ thermocouples (which are operational up to $1100^{\circ} \mathrm{C}$ ). The thermocouples were located at two locations within the $200 \mathrm{~mm}$ thick large specimens (in the centre and centroid of the top quadrant) and only at the centre for all the other specimens. For example, the coordinates for these locations would be $(150,150 \mathrm{~mm})$ and $(225,225 \mathrm{~mm})$ for the $300 \times 300 \mathrm{~mm}$ specimens of $200 \mathrm{~mm}$ thickness etc.

The depths of the in-situ thermocouples were at depths of $25 \mathrm{~mm}$ for the $50 \mathrm{~mm}$ thick specimens, 25,50 and $75 \mathrm{~mm}$ for the $100 \mathrm{~mm}$ thick specimens and 25, 50, 75, 100 and $150 \mathrm{~mm}$ for the $200 \mathrm{~mm}$ specimens. Thermocouple measurements were also taken at the centre of both the fire side and non exposed fire side for all specimens.

Due to the high cost of the pore pressure gauges, and the complexity and time involvement needed in setup, pore pressure measurements [gauges max recording (10 MPa)] were only taken for the $200 \mathrm{~mm}$ specimens. The location of these measurements were taken $5 \mathrm{~mm}$ away from the centre of the panels in order to avoid any disturbance from the in-situ temperature measurements. The measurements were taken at 25, 50, 75, 100 and 150 from the heated face. The setup used for the pore pressure measurements is in alignment with the works of [9-11] which describes the procedure in detail. Essentially, a pipe of length $300 \mathrm{~mm}$ and inside diameter of $5 \mathrm{~mm}$ is located at the measurement point and extends out on the non exposed side of the concrete panel. The pipe is then filled with high temperature silicone oil and connected to the pore pressure gauge. The system is then entirely bled with the silicone oil. The concept is that the pore pressures at the measurement point are transformed via the silicone oil into the pore pressure gauge.

\subsection{Spalling observations, 3d surface mapping, volume and mass loss}

To quantity the degree of spalling, the intrados side if the test segments were measured with a Leica TPS1200+ tachymeter prior to the test and 24 hours after the specimens were exposed to fire. Using cross sections over the longitudinal axis of the specimens, at a spacing of $15 \mathrm{~mm}$, 3D images were generated which represented the spalling depths and subsequently spalling damage contours. The computer software program OriginPro 8.5 was used to generate these contour plots and give an insight into the degree and orientation of spalling. The software was also used to perform a $2 \mathrm{D}$ volume integration which represents the total volume of concrete spalled from the surface. From this data, using a uniform constant concrete density of $2400 \mathrm{~kg} / \mathrm{m}^{3}$ the total mass loss of spalled concrete could be determined. The specimens were also weighed before and after temperature exposure. Therefore, the difference between the initial weights and mass of concrete spalling represents the mass of water loss. This represents a key finding as this mass loss of water is related to the built-up of pore water pressure which is a key mechanism believed to cause concrete spalling [10, 12-16]. Visual observations through the viewing ports and acoustic observations were also recorded as a function of time as these observations indicate the occurrence of concrete spalling.

\section{EXPERIMENTAL RESULTS AND DISCUSSION}

The behavior of the concrete panels subjected to fire is discussed in brief relating to 1) thermal analysis, 2) pore pressure build-up, 3) spalling behavior and 4) mass loss. Due to the independency of all these four areas of influence, the discussion and analysis of results at times will be repeated broadly. Figures 2 , 3 and 4 below represent the spalling 3D surface contour maps.

Tables 2 and 3 below represents the spalling depths of the specimens at the locations described earlier which represent the locations where the insitu temperature and pore pressure readings were taken. In addition, the tables also illustrates whether the temperature and pore pressure data recorded was valid and the duration of the valid period. For instance, specimen S200-80 indicated that at the centre 


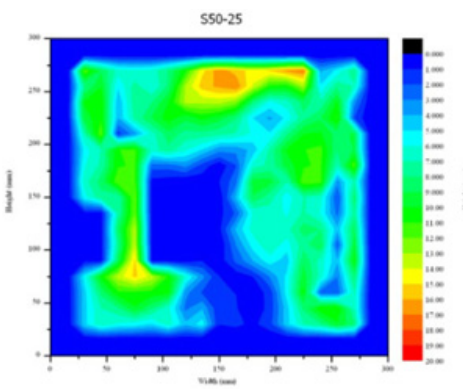

$550-80$

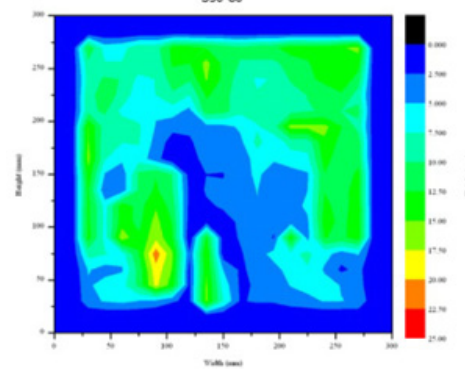

$5100-25$

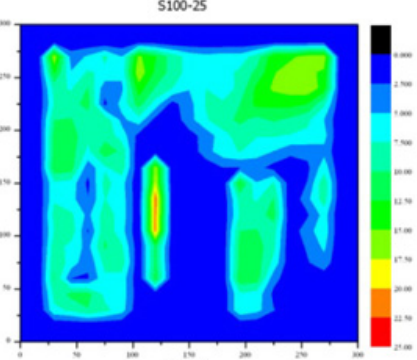

$\$ 100-80$

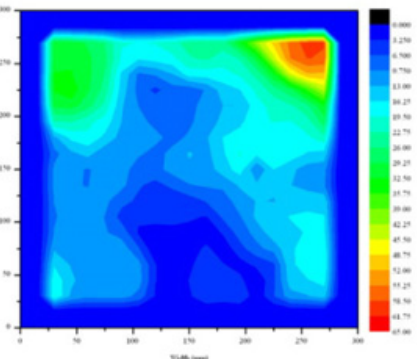

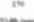

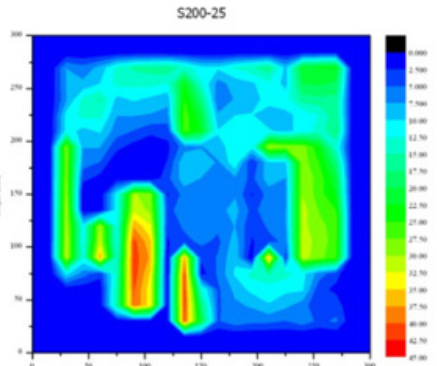

$5200-80$

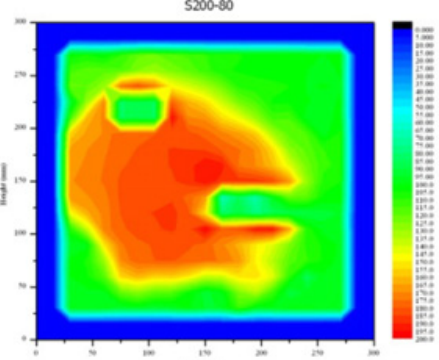

Figure 2. Spalling depth contour maps for $300 \times 300 \mathrm{~mm}$ specimens.
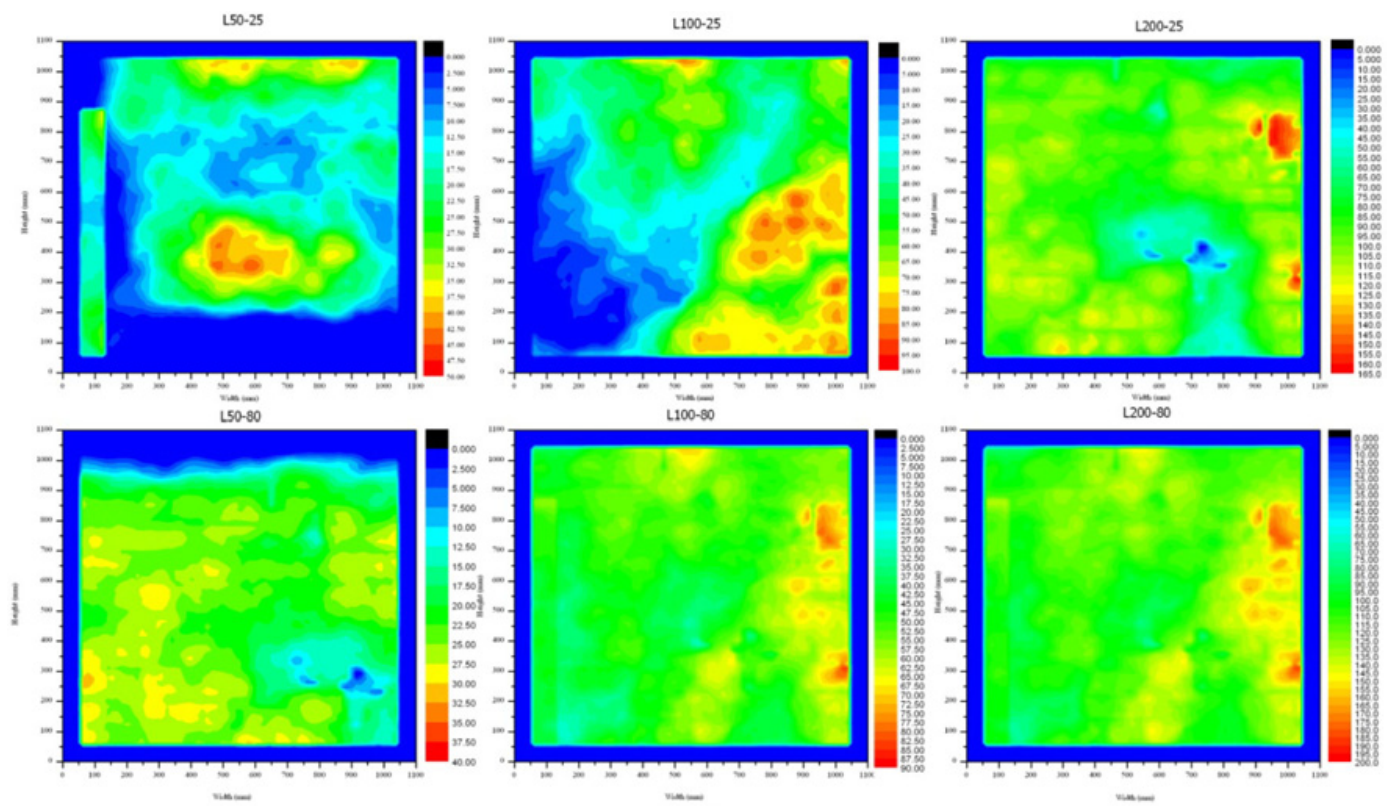

Figure 3. Spalling depth contour maps for $1100 \times 1100 \mathrm{~mm}$ specimens.

(as can be seen in Fig. 2 above), the spalling depth was in the order of $194.22 \mathrm{~mm}$. This indicates that at particular point in time, the insitu data recordings would not be valid for the 25, 50, 75, 100 and $150 \mathrm{~mm}$ recordings since at these location depths, the recordings would no longer be insitu.

There is a wealth of literature regarding the profiles of insitu temperature recordings for concrete specimens subjected to fire and therefore these results are not presented within this research paper. This 

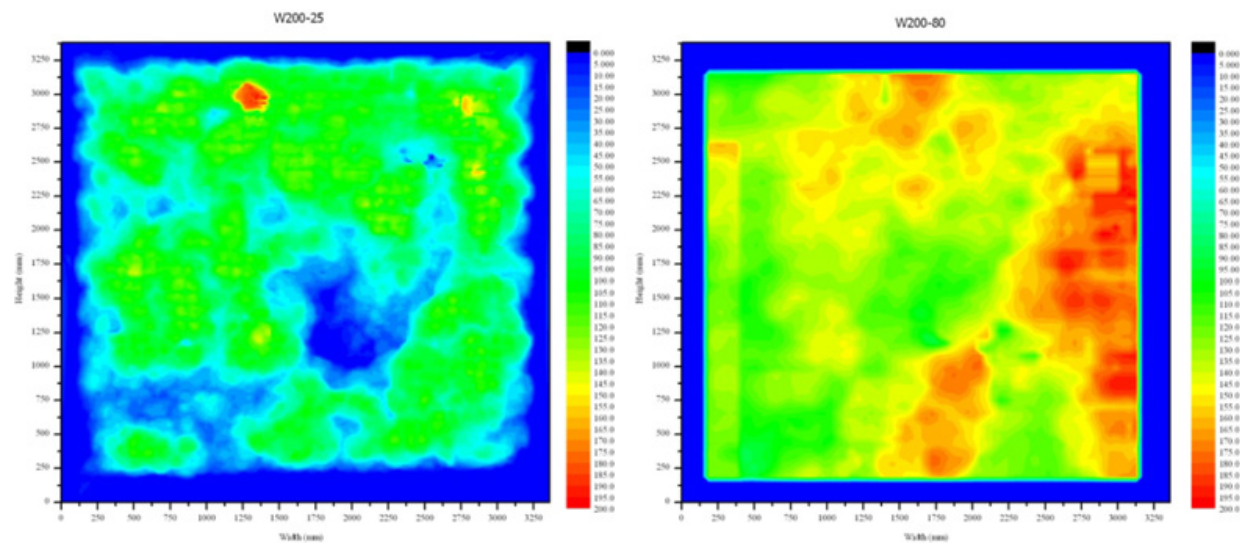

Figure 4. Spalling depth contour maps for $3360 \times 3380 \mathrm{~mm}$ specimens.

Table 2. Specimen insitu measurements.

\begin{tabular}{|c|c|c|c|c|c|c|c|c|c|c|c|c|}
\hline \multirow[b]{2}{*}{$\begin{array}{l}\text { Specimen } \\
\text { ID }\end{array}$} & \multicolumn{2}{|c|}{ Spalling Depths } & \multicolumn{5}{|c|}{$\begin{array}{l}\text { Temp Recorded Valid- } \\
\text { Centre. }(200 \mathrm{~mm} \text { specimens } \\
\text { also represent pore } \\
\text { pressure results). }\end{array}$} & \multicolumn{5}{|c|}{ Mins Temp Valid - Centre } \\
\hline & Centre & Quadrant & $\begin{array}{c}25 \\
\mathrm{~mm}\end{array}$ & $\begin{array}{c}\mathbf{5 0} \\
\mathbf{m m}\end{array}$ & $\begin{array}{c}75 \\
\mathrm{~mm}\end{array}$ & $\begin{array}{l}100 \\
\mathrm{~mm}\end{array}$ & $\begin{array}{l}150 \\
\mathrm{~mm}\end{array}$ & $\begin{array}{c}25 \\
\mathbf{m m}\end{array}$ & $\begin{array}{c}\mathbf{5 0} \\
\mathbf{m m}\end{array}$ & $\begin{array}{c}75 \\
\mathrm{~mm}\end{array}$ & $\begin{array}{l}100 \\
\mathrm{~mm}\end{array}$ & $\begin{array}{l}150 \\
\mathrm{~mm}\end{array}$ \\
\hline S50-25 & 0.21 & - & ok & ok & ok & ok & ok & 60 & 60 & 60 & 60 & 60 \\
\hline S100-25 & 0.51 & - & ok & ok & ok & ok & ok & 60 & 60 & 60 & 60 & 60 \\
\hline S200-25 & 6.60 & 9.22 & ok & ok & ok & ok & ok & 60 & 60 & 60 & 60 & 60 \\
\hline S50-80 & 2.44 & - & ok & ok & ok & ok & ok & 60 & 60 & 60 & 60 & 60 \\
\hline S100-80 & 12.36 & - & ok & ok & ok & ok & ok & 60 & 60 & 60 & 60 & 60 \\
\hline S200-80 & 194.22 & 103.39 & fail & fail & fail & fail & fail & 4 & 4 & 13 & 18 & 22 \\
\hline L50-25 & 21.47 & - & ok & ok & ok & ok & ok & 60 & 60 & 60 & 60 & 60 \\
\hline L100-25 & 26.52 & - & fail & ok & ok & ok & ok & 6.17 & 60 & 60 & 60 & 60 \\
\hline L200-25 & 75.00 & 97.69 & fail & fail & fail & ok & ok & 7 & 15 & 20 & 60 & 60 \\
\hline L50-80 & 24.16 & - & ok & ok & ok & ok & ok & 60 & 60 & 60 & 60 & 60 \\
\hline L100-80 & 40.85 & - & fail & ok & ok & ok & ok & 6.33 & 60 & 60 & 60 & 60 \\
\hline L200-80 & 98.73 & 111.29 & fail & fail & fail & ok & ok & 8 & 9 & 9 & 60 & 60 \\
\hline W200-25 & 31.27 & 34.55 & fail & ok & ok & ok & ok & 7 & 60 & 60 & 60 & 60 \\
\hline W200-80 & 118.58 & 142.88 & fail & fail & fail & fail & ok & 6 & 6 & 6 & 7 & 60 \\
\hline
\end{tabular}

Table 3. Specimen insitu measurements - Continued.

\begin{tabular}{|c|c|c|c|c|c|c|c|c|c|c|c|c|c|c|c|}
\cline { 2 - 2 } & \multicolumn{4}{c|}{ Temp Recorded Valid - } & \multicolumn{4}{c|}{ Mins Temp Valid-Quadrant } & \multicolumn{4}{c|}{ Mins Pore Pressure Valid } \\
\hline \begin{tabular}{|c|c|c|c|c|c|c|c|c|c|c|c|c|c|c|c|c|c|c|}
\multicolumn{1}{c|}{} \\
$\begin{array}{c}\text { Specimen } \\
\text { ID }\end{array}$
\end{tabular} & $\begin{array}{c}\mathbf{2 5} \\
\mathbf{m m}\end{array}$ & $\begin{array}{c}\mathbf{5 0} \\
\mathbf{m m}\end{array}$ & $\begin{array}{c}\mathbf{7 5} \\
\mathbf{m m}\end{array}$ & $\begin{array}{c}\mathbf{1 0 0} \\
\mathbf{m m}\end{array}$ & $\begin{array}{c}\mathbf{1 5 0} \\
\mathbf{m m}\end{array}$ & $\begin{array}{c}\mathbf{2 5} \\
\mathbf{m m}\end{array}$ & $\begin{array}{c}\mathbf{5 0} \\
\mathbf{m m}\end{array}$ & $\begin{array}{c}\mathbf{7 5} \\
\mathbf{m m}\end{array}$ & $\begin{array}{c}\mathbf{1 0 0} \\
\mathbf{m m}\end{array}$ & $\begin{array}{c}\mathbf{1 5 0} \\
\mathbf{m m}\end{array}$ & $\begin{array}{c}\mathbf{2 5} \\
\mathbf{m m}\end{array}$ & $\begin{array}{c}\mathbf{5 0} \\
\mathbf{m m}\end{array}$ & $\begin{array}{c}\mathbf{7 5} \\
\mathbf{m m}\end{array}$ & $\begin{array}{c}\mathbf{1 0 0} \\
\mathbf{m m}\end{array}$ & $\begin{array}{c}\mathbf{1 5 0} \\
\mathbf{m m}\end{array}$ \\
\hline S200-25 & ok & ok & ok & ok & ok & 60 & 60 & 60 & 60 & 60 & 60 & 60 & 60 & 60 & 60 \\
\hline S200-80 & fail & fail & fail & fail & ok & 5.67 & 11.33 & 19.83 & 45.50 & 60 & 4 & 4 & 13 & 18 & 22 \\
\hline L200-25 & fail & fail & fail & ok & ok & 9.83 & 10.17 & 15.50 & 60 & 60 & 7 & 15 & 20 & 60 & 60 \\
\hline L200-80 & fail & fail & fail & fail & ok & 6.33 & 6.33 & 6.33 & 7.33 & 60 & 8 & 9 & 9 & 60 & 60 \\
\hline W200-25 & fail & ok & ok & ok & ok & 4.17 & 60 & 60 & 60 & 60 & 7 & 60 & 60 & 60 & 60 \\
\hline W200-80 & fail & fail & fail & fail & ok & 4.17 & 4.17 & 6.33 & 7.33 & 60 & 6 & 6 & 6 & 7 & 60 \\
\hline
\end{tabular}




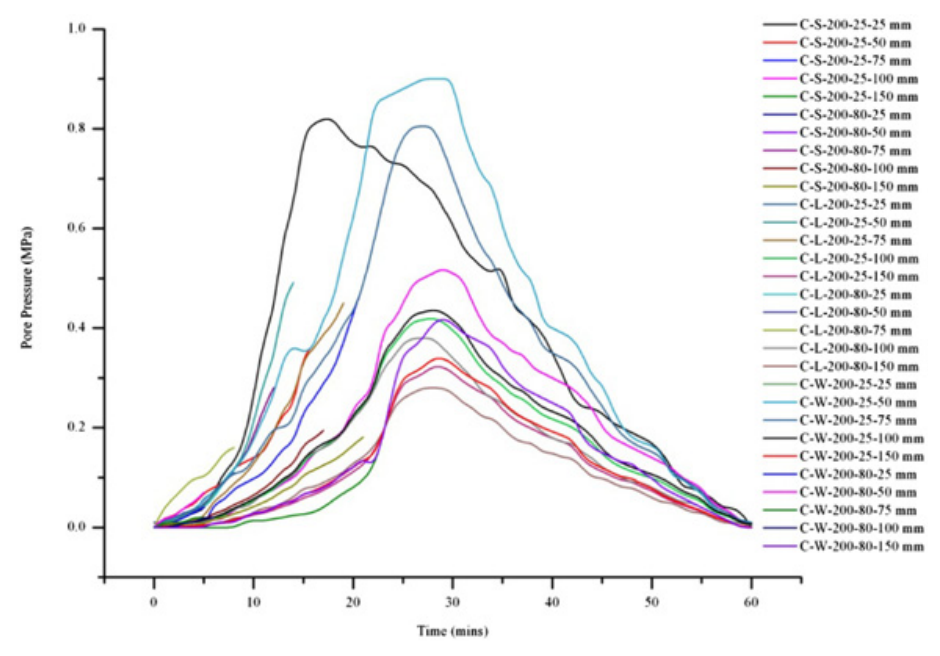

Figure 5. Insitu pore pressure measurements.

is because they shed no real light regarding the spalling phenomenon and only illustrate the typical and expected heat and mass transfer between a hot and cold boundary. Guerrieri \& Fragomeni [17] present these findings based on similar panels tested in this research. The authors of this paper used the spikes recorded in the insitu temperature recordings to determine the time when spalling occurred as explained earlier which is vital in proper analyses of the pore pressure profiles illustrated in 5 below.

The following discussion is based on the insitu pore pressure measurements for Specimen S200-25 which only had a total spalling depth of $6.60 \mathrm{~mm}$ as illustrated in Table 2 above and therefore all pore pressure gauges remained in-situ. This profile illustrates the classic "moisture clog" mechanism theory explained in detailed elsewhere $[3,18,19]$ as the peak pore water pressure is between the heated face and unexposed surface, a location that is believed to be completely saturated caused by moisture being clogged. Under continuous heating, this moisture clog builds up enough pressure to cause explosive spalling to take place since the build-up of pore water pressure is greater than the tensile strength of concrete.

Given the fact that the magnitude of spalling varied between locations and between specimen sizes and thicknesses, as can be seen from the spalling mapping contours shown in Figures 2-4 and Tables 2-3 respectively it is difficult and inaccurate to pinpoint and quantify the various spalling mechanisms at play. This is further enforced by the fact that specimen S200-25 recorded a maximum pore water pressure of around $0.9 \mathrm{MPa}$ without spalling whilst other specimens underwent spalling at pore pressures as low as $0.2 \mathrm{MPa}$. These discrepancies have been reported elsewhere in the literature [15].

\section{CONCLUSION}

This research has shown that the erratic behavior of concrete spalling makes it difficult to justify results and establish the mechanisms of spalling. Irregularities arise from the fact that the non-homogenous nature of concrete causes spalling being attributed to inter-dependent factors and the fire exposure it has been subjected too. Often, explosive spalling has occurred to only a few specimens from a larger group of specimens that were subjected to identical testing conditions [4-6].

Key findings [2, 3, 18-23] argue that that explosive spalling occurs due to the build-up of pore water pressure "moisture-clog mechanism" whilst other key findings [24-26] suggest that explosive spalling is caused by differential thermal gradients within the concrete element. The authors of this paper agree 


\section{MATEC Web of Conferences}

with the recent consensus towards the combination of build-up of pore pressure and differential thermal gradients $[3,15,24]$ however, they also believe that concrete spalling in fire is also governed by other inter-dependent factors such as compressive strength, specimen size and thickness as was shown in the research presented in this paper.

\section{References}

[1] Ashe, B, Total cost of fire in Australia. Journal of Risk Research, 2009. 12(2): p. 121-136.

[2] Harmathy, T., Effect of moisture on fire endurance of building elements. 1965, American Society for Testing and Materials: Philadelphia. p. 74-95.

[3] Khoury, G., et al., Modelling of heated concrete. Mag of Concrete Research, 2002. 54(2): p. 77101.

[4] Phan, L., Fire performance of high-strength concrete: a report of the state of-the-art. 1996, Building and Fire Research Laboratory, National Institute of Standards and Technology: Gaithersburg.

[5] Phan, L. and N. Carino, Review of mechanical properties of HSC at elevated temperature. Journal of Materials in Civil Engineering, 1998. 10(1): p. 58-64.

[6] Phan, L., J. Lawson, and F. Davis, Effects of elevated temperature exposure on heating characteristics, spalling, and residual properties of high concrete. Materials and Structures, 2001. 34(1): p. 83-91.

[7] American Society for Testing of Materials 2007, Construction and Materials (ASTM E119-07a).

[8] Australian Standard AS1530.4 1997

[9] Bangi, M.R. and T. Horiguchi, Pore pressure development in hybrid fibre-reinforced high strength concrete at elevated temperatures. Cement and Concrete Research, 2011. 41(11): p. 1150-1156.

[10] Jansson, R. Liquid/steam pressure measurement inside concrete exposed to fire. in Structures in fire 06, proceedings from the 4th international workshop, Aveiro, Portugal. 2006.

[11] Mindeguia, J.-C., et al., Temperature, pore pressure of concrete subjected to temperature Experimental discussion on spalling. Cement and Concrete Research, 2010. 40(3): p. 477-487.

[12] Chen, X.T., et al., Experimental evidence of a moisture clog effect in cement-based materials under temperature. Cement and Concrete Research, 2009. 39(12): p. 1139-1148.

[13] Jansson, R. and L. Bostrom, The influence of pressure in the pore system on fire spalling of concrete. Fire Technology, 2010. 46(1): p. 217-230.

[14] Ko, J., D. Ryu, and T. Noguchi, The spalling mechanism of high-strength concrete under fire. Magazine of Concrete Research, 2011. 63(5): p. 357-370.

[15] Phan, L.T., Pore pressure and explosive spalling in concrete. Materials and Structures/Materiaux et Constructions, 2008. 41(10): p. 1623-1632.

[16] Simon, H., G. Nahas, and N. Coulon, Air-steam leakage through cracks in concrete walls. Nuclear Engineering and Design, 2007. 237(15-17): p. 1786-1794.

[17] Guerrieri, M. and S. Fragomeni, Influence of in-situ pore pressures and temperatures on spalling of reinforced concrete walls subjected to fire, in ACMSM22. 2012: Sydney.

[18] Consolazio, G., M. McVay, and J. Rish, Measurement and prediction of pore pressures in saturated cement mortar subjected to radiant heating. ACI Materials Journal, 1998. 95(5): p. 525-536.

[19] Harada, K. and T. Terai, Heat and mass transfer in the walls subjected to fire. 1997, Building and Fire Research Laboratory, National Institute of Standards and Technology: Gaithersburg, MD. p. 423-435.

[20] Anderberg, Y., Spalling phenomena of HPC and OPC. 1997, Building and Fire Research Laboratory, National Institute of Standards and Technology: Gaithersburg, MD. p. 69-73.

[21] Kalifa, P., G. Chene, and C. Galle, High-temperature behaviour of HPC with polypropylene fibres - from spalling to microstructure. Cement and Concrete Research, 2001. 31(10): p. 1487-1499. 
[22] Khoury, G., Compressive strength of concrete at high temperatures: a reassessment. Magazine of Concrete Research, 1992. 44(161): p. 291-309.

[23] Khoury, G., Concrete spalling assessment methodologies and polypropylene fibre toxicity analysis in tunnel fires. Structural Concrete, 2008. 9(1): p. 11-18.

[24] Bazant, Z.P. Analysis of pore pressure, thermal stresses and fracture in rapidly heated concrete. in International Workshop on Fire Performance of High-Strength Concrete. 1997. Gettysburg: NIST.

[25] Nechnech, W., F. Meftah, and J. Reynouard, An elasto-plastic damage model for plain concrete subjected to high temperatures. Engineering Structures, 2002. 24(5): p. 597-611.

[26] Ulm, F.J., O. Coussy, and Z.P. Bazant, The "Chunnel" fire. I: Chemoplastic softening in rapidly heated concrete. Journal of engineering mechanics, 1999. 125(3): p. 272-282. 